\title{
PENGARUH KUALITAS LAYANAN DAN CITRA MEREK TERHADAP LOYALITAS MELALUI KEPUASAN NASABAH PERUM PEGADAIAN CABANG BEKASI TIMUR
}

\author{
Arry Dwi Syahputra *) \\ *) Mahasiswa Program Studi Manajemen FE UNKRIS \\ Alamat: Kampus UNKRIS, Jatiwaringin Jakarta Timur \\ Email : arrydwisyahputra@gmail.com
}

\begin{abstract}
This study aims to analyze the effect of service quality and brand image on customer loyalty through customer satisfaction at Perum Pegadaian Timur Bekasi Branch. The study was conducted at Perum Pegadaian Timur Bekasi Branch. Sampling of research using probability sampling and simple random sampling methods. Data analysis uses path analysis. Based on data analysis, it is known that partially each of the independent variables is service quality, brand image and customer satisfaction has an influence on customer loyalty at Perum Pegadaian, East Bekasi Branch. Then the results of the analysis of customer satisfaction variables as intervening variables can be proved perfectly that customer satisfaction variables indirectly influence the service quality variable on customer loyalty and brand image variables on customer loyalty. This statement can be proven by the magnitude of the indirect effect (service quality on customer loyalty and brand image on customer loyalty) through customer satisfaction identified as an intervening variable.
\end{abstract}

Keywords: Service quality, brand image, customer satisfaction and customer loyalty

\section{PENDAHULUAN}

Adanya kebutuhan manusia yang tidak terbatas tenyata menimbulkan permasalahan yang cukup besar untuk dicarikan solusinya. Walaupun sekarang perkembangan zaman penuh dengan berbagai kemajuan disegala bidang dengan terbatasnya alat teknologi menjadi kendala utama dari penyelesaian masalah. Persaingan global menunjuk setiap perusahaan untuk dapat meningkatkan kualitas layanan yang nantinya akan menunjang terwujudnya kepuasan pelanggan, apabila semakin tinggi persaingan antar perusahaan maka akan membuat perusahaan berusaha untuk meningkatkan keterampilan untuk memberikan layanan kepada pelanggan.

Perusahaan yang memiliki keterampilan yang tinggi dalam memberikan layanan akan mampu menguasai pasar, bahkan mendominasi pasar. Lewat kegiatan pemasaran yang efektif, tentunya upaya untuk semakin dekat dengan pelanggan harus terus dibina yang secara tidak langsung akan berdampak pada kelangsungan dan pengembangan perusahaan. Perusahaan-perusahaan jasa terutama dalam hal ini jasa perkreditan, mempunyai arti yang sangat strategis, baik dalam rangka mendukung perekonomian masyarakat Indonesia yang sehat. Sekaligus sebagai keberhasilan pelaksanaan kegiatan bisnis dalam rangka untuk dapat meraih keuntungan yang telah di rencanakan.

Salah satu perusahaan perkreditan di Indonesia adalah Perum Pegadaian yang merupakan satu-satunya lembaga pemerintah yang bergerak dibidang jasa penyaluran uang pinjaman bagi masyarakat atas dasar Hukun gadai dengan jaminan barang bergerak. Berdasarkan PP 103 tanggal 10 November 2000, Perum Pegadaian memiliki misi ikut membangun program pemerintah dalam upaya meningkatkan kesejahteraan masyarakat golongan menengah kebawah melalui kegiatan utama berupa penyaluran kredit gadai dan 
melakukan usaha lain yang menguntungkan, serta untuk mencegah praktek-praktek ijon, pegadaian gelap, riba dan pinjaman tidak wajar lainnya. Oleh karena itu, barang-barang yang diterima sebagai jaminan kreditpun sangat bervariasai mulai dari bahan kain, barang perhiasan ( logam dan permata ), kendaraan, barang rumah tangga sampai saham-saham dan surat-surat berharga. Besarnya kredit yang diberikan sangat bervariasi dari hanya Rp.20.ribu- sampai dengan Rp.1 milyar.

Meskipun pegadaian memiliki berbagai keunggulan sebagaimana dikemukakan di atas, ternyata masih banyak masyarakat yang terjebak dengan praktek-praktek rentenir dan pegadaian gelap lainnya. Ini berarti ada rasa tidak nyaman untuk melakukan kredit di pegadaian. Selama ini pegadaian identik dengan orang kecil yang kekurangan dana. Hal ini bisa di mengerti, karena yang antri mengadaikan barang, kebanyakan berasal dari masyarakat golongan menengah kebawah. Demikian pula produknya, selama ini masyarakat hanya mengetahui, Pegadaian hanya melayani jasa gadai saja. Padahal, produk Pegadaian sebenarnya cukp banyak, seperti jasa taksiran, jasa titipan, galeri 24 dan koin emas, usaha persewaan gudang, unit produksi perhiasan emas dan balai lelang. Masyarakat cenderung mencari kemudahan dengan meminjam para rentenir dan gadai gelap yang ada pada akhirnya menimbulkan kerugian bagi diri sendiri. Paradigma inilah yang harus dihapus oleh para pengelola perum pegadaian, salah satunya adalah dengan tetap mempertahankan kepercayaan pelanggan (selanjutnya disebut sebagai nasabah) dengan tujuan memberikan kepuasan yang maksimal bagi para pelanggannya, sehingga pelanggan tersebut menjadi nasabah yang loyal, tidak akan menggunakan jasa gadai lain selain jasa perum pegadaian dan bahkan menjadi alat promosi di lingkungan nasabah tersebut.

Kepuasan dan loyalitas nasabah tidak lepas dari persepsi atas kualitas yang dirasakan oleh nasabah. Oleh karena itu, persepsi atas kualitas layanan merupakan tanggung jawab perusahaan atas produk yang ditawarkan, dengan turut memberikan kemudahan yang menguntungkan serta memberi nilai lebih bagi nasabah dan akhirnya akan tercipta suatu kepuasan dalam diri nasabah tersebut.

Dengan menyadari akan arti pentingnya kualitas layanan yang baik, maka perum pegadaian berupaya meningkatkan kualitas layanannya, baik dengan cara memberikan tambahan fasilitas maupun kemudahan dalam peminjaman. Meskipun terkadang peningkatan kualitas layanan telah dianggap baik oleh pihak perusahaan, belum tentu akan dapat memberikan kepuasan nasabah dan menjadi nasabah loyal. Hal yang menarik adalah bagaimanakah dengan kualitas layanan, citra merek dan kepuasan, nasabah Perum Pegadaian menjadi loyal. Oleh karena itu, tujuan penelitian ini adalah untuk menganalisis pengaruh kualitas layanan dan citra merek terhadap loyalitas melalui kepuasan nasabah Perum Pegadaian Cabang Bekasi Timur.

Tabel 1. Jumlah Nasabah Perum Pegadaian Cabang Bekasi Timur

\begin{tabular}{cc}
\hline Tahun & Jumlah Nasabah \\
\hline 2010 & 2146 \\
2011 & 2309 \\
2012 & 2290 \\
2013 & 2548 \\
2014 & 2451 \\
\hline
\end{tabular}

Sumber: Perum Pegadaian Cabang Bekasi Timur 2014 


\section{LANDASAN TEORI}

\section{Kualitas Layanan}

Kotler dan Keller (2009) mendefinisikan jasa sebagai "any act or perfomance that one party can offer another that is essensially intangible and does not result in the ownership of anything. It's production may or not be tired to a physical product". Pernyataan ini diartikan sebagai bahwa setiap aktivitas, manfaat atau performance yang ditawarkan oleh satu pihak ke pihak lain yang bersifat intangible dan tidak menyebabkan perpindahan kepemilikan apapun dimana dalam produksinya dapat terikat maupun tidak dengan produksi fisik.

Berdasarkan definisi tersebut dapat dilihat bahwa terdapat perbedaan yang cukup jelas antara produk yang berupa jasa dengan produk yang berupa barang. Jasa merupakan serangkaian kegiatan tindakan atau aktivitas yang ditawarkan oleh suatu pihak kepada pihak lain yang pada dasarnya tidak berwujud, dapat memberikan nilai tambah tanpa menyebabkan perubahan kepemilikan (transfer of ownership) walaupun dalam produksinya, jasa dapat melibatkan produk fisik untuk mendukungnya.

Karakteristik jasa adalah suatu sifat dari jasa yang ditawarkan oleh suatu pihak ke pihak lain yang berfungsi untuk membedakan dengan produk atau barang. Kotler dan Amstrong (2009) mengemukakan bahwa ada empat karakteristik jasa, antara lain sebagai berikut: 1). Tidak berwujud (intangibility); Jasa bersifat abstrak dan tidak berwujud, dalam hal ini jasa tidak seperti halnya produk fisik, jasa tidak dapat dilihat, dirasa, diraba, didengar, dicium sebelum jasa itu dibeli atau digunakan. Dalam upaya mengurangi ketidakpastian ini, maka para calon pembeli akan mencari tanda atau bukti dari kualitas mutu jasa. Dalam mencari bukti kualitas layanan jasa nasabah akan melakukan beberapa penilaian, antara lain sebagai berikut: a). Tempat (place); Tempat yang mendukung seperti kebersihan yang terjaga, kenyamanan untuk nasabah, dan suasana yang mendukung. b). Orang (people); Orang yang menangani mampu melaksanakan tugas dengan baik, sudah terlatih, cepat dalam menangani masalah. c). Peralatan (equipment); Peralatan penunjang seperti komputer, meja, mesin fax, dan lainnya. d). Komunikasi material (communication material); Bukti-bukti berupa teks tertulis dan foto, misalnya kontrak atau hasil jadi dalam foto. e). Simbol (symbol); Nama dan symbol pemberi jasa mencerminkan kemampuan dan kelebihannya dalam melayani nasabah. f). Harga (price); Harga yang masuk akal dan dapat pula dipadukan dengan berbagai macam promosi penjualan, seperti bonus, diskon, dan lain-lain. 2). Bervariasi (variability). Jasa bersifat nonstandar dan sangat variabel. Berbeda dengan kualitas produk fisik yang sudah terstandar, kualitas layanan jasa bergantung pada siapa penyedianya, kapan, dimana, dan bagaimana jasa itu diberikan. Oleh karena itu jasa sangat bervariasi dan berbeda satu dengan lainnya. 3). Tidak dapat dipisahkan (inseparability). Jasa umumnya diproduksi dan dikonsumsi pada waktu yang bersamaan dengan partisipasi nasabah didalamnya. 4). Tidak dapat disimpan (pershability). Jasa tidak mungkin disimpan dalam bentuk persediaan. Nilai jasa hanya ada pada saat jasa tersebut diproduksi dan langsung diterima oleh pengguna jasa. Karakteristik seperti ini berbeda dengan barang berwujud yang dapat diproduksi terlebih dahulu, disimpan dan dipergunakan lain waktu.

Tjiptono (2011) pengukuran yang dapat digunakan dalam mengukur dimensi kualitas layanan jasa antara lain: 1). Keandalan (reliability) yaitu kemampuan memberikan layanan 
yang dijanjikan dengan segera, akurat dan memuaskan. 2). Daya tanggap (responsiveness) yaitu keinginan para staf untuk membantu para pelanggan dan memberikan layanan dengan tanggap. 3). Jaminan (asurance) mecakup pengetahuan, kemampuan, kesopanan, dan sifat dapat dipercaya yang dimiliki para staf bebas dari bahaya, risiko atau keraguan. 4). Empati (empathy) meliputi kemudahan dalam melakukan hubungan komunikasi yang baik, perhatian pribadi, dan memahami kebutuhan para pelanggan. 5). Bukti langsung (tangibles) meliputi fasilitas fisik, perlengkapan, karyawan, serta sarana komunikasi.

\section{Citra Merek}

Roslina (2010) mendefinisikan citra merek sebagai kumpulan asosiasi yang diorganisir menjadi suatu yang berarti. Citra merek berdasarkan memori konsumen tentang suatu produk, sebagai akibat dari apa yang dirasakan oleh seseorang terhadap merek tersebut. Perasaan yang menyenangkan atau tidak menyenangkan terhadap suatu merek akan membentuk citra tersebut dan akan tersimpan dalam memori konsumen. Citra merek merupakan asosiasi yang muncul dalam benak konsumen ketika mengingat suatu merek tertentu. Asosiasi tersebut secara sederhana dapat muncul dalam bentuk pemikiran dan citra tertentu yang dikaitkan dengan suatu merek.

Menurut Tjiptono (2011), brand image atau brand description yakni deskripsi tentang asosiasi dan keyakinan konsumen terhadap merek tertentu. Sejumlah teknik kuantitatif dan kualitatif telah dikembangkan untuk membantu mengungkap presepsi dan asosiasi konsumen terhadap sebuah merek tertentu, diantaranya multi-dimensional scaling, projection techniques, dan sebagainya. Keller (1993) menyatakan bahwa "brand image is perceptions about brand as reflected by the brand association held in consumen memory", bahwa asosiasi merek berlaku sebagai pusat informasi yang terhubung ke memori otak dan mengandung arti dari merek tersebut untuk konsumen. Berdasarkan pendapat para ahli tersebut, citra merek dalam penelitian ini didefinisikan sebagai persepsi nasabah tentang suatu merek, dimana berdasarkan memori nasabah tentang suatu produk, sebagai akibat dari apa yang dirasakan oleh seseorang terhadap merek tersebut.

Keller (1993) mengemukakan brand image yang kuat di benak pelanggan dibentuk dari 3 unsur, yaitu: 1). Keunggulan asosiasi merek (favorability of brand association). Keunggulan asosiasi merek dapat membuat konsumen percaya bahwa atribut dan manfaat yang diberikan oleh suatu merek dapat memuaskan kebutuhan dan keinginan konsumen sehingga menciptakan sikap yang positif terhadap merek tersebut. Tujuan akhir dari setiap konsumsi yang dilakukan oleh konsumen adalah mendapatkan kepuasan akan kebutuhan dan keinginan. Adanya kebutuhan dan keinginan dalam diri konsumen melahirkan harapan, dimana harapan tersebut yang diusahakan oleh konsumen untuk dipenuhi melalui kinerja produk dan merek yang dikonsumsinya. Apabila kinerja produk atau merek melebihi harapan, maka konsumen akan puas, dan demikian juga sebaliknya. Dapat disimpulkan bahwa keunggulan asosiasi merek terdapat pada manfaat produk, tersedianya banyak pilihan untuk memenuhi kebutuhan dan keinginan, harga yang ditawarkan bersaing, dan kemudahan mendapatkan produk yang dibutuhkan serta nama prusahaan yang bonafit juga mampu menjadi pendukung merek tersebut. 2). Kekuatan asosiasi merek (strenght of brand association). Kekuatan asosiasi merek, tergantung pada bagaimana informasi masuk dalam ingatan konsumen dan bagaimana informasi tersebut dikelola oleh data sensoris di otak sebagai bagian dari brand image. Ketika konsumen secara aktif memikirkan dan menguraikan arti informasi pada suatu produk atau jasa maka akan tercipta asosiasi yang semakin kuat pada ingatan konsumen. Konsumen memandang suatu 
objek stimuli melalui sensasi-sensasi yang mengalir lewat kelima indera: mata, telinga, hidung, kulit, dan lidah. Namun demikian, setiap konsumen mengikuti, mengatur, dan mengiterprestasikan data sensoris ini menurut cara masing-masing. Persepsi tidak hanya tergantung pada stimulasi fisik tetapi juga pada stimulasi yang berhubungan dengan lingkungan sekitar dan keadaan individu tersebut. Perbedaan pandangan pelanggan atas sesuatu objek (merek) akan menciptakan proses persepsi dalam prilaku pembelian yang berbeda. 3). Keunikan asosiasi merek (uniqueness of brand association). Sebuah merek haruslah unik dan menarik sehingga produk tersebut memiliki ciri khas dan sulit untuk ditiru oleh para produsen pesaing. Melalui keunikan suatu produk maka akan memberi kesan yang cukup membekas terhadap ingatan pelanggan akan keunikan brand atau merek produk tersebut yang membedakannya dengan produk sejenis lainnya. Sebuah merek yang memiliki ciri khas haruslah dapat melahirkan keinginan pelanggan mengetahui lebih jauh dimensi merek yang terkandung didalamnya. Merek hendaknya mampu menciptakan motivasi pelanggan untuk mulai mengkonsumsi produk bermerek tersebut. Merek juga hendaknya mampu menciptakan kesan yang baik bagi pelanggan yang mengkonsumsi produk dengan merek tersebut.

\section{Kepuasan Nasabah}

Day dalam Tse dan Wilton yang dikutip Tjiptono (2009) menyatakan bahwa kepuasan atau ketidakpuasan nasabah adalah respon nasabah terhadap evaluasi ketidaksesuaian (disconfirmation) yang dirasakan antara harapan sebelumnya (atau norma kinerja lainnya) dan kinerja aktual produk yang dirasakan setelah pemakaiannya, sedangkan Wilkie yang dikutip Tjiptono (2009) mendefinisikan sebagai suatu tanggapan emosional pada evaluasi terhadap pengalaman konsumsi suatu produk atau jasa. Kemudian Engel, et al yang dikutip Tjiptono (2009) menyatakan bahwa kepuasan nasabah merupakan evaluasi purna beli dimana alternatif yang dipilih sekurang-kurangnya sama atau melampaui harapan nasabah, sedangkan ketidakpuasan muncul apabila hasil (outcome) tidak memenuhi harapan.

Setelah melihat definisi-definisi tersebut, dapat diketahui bahwa pada dasarnya pengertian kepuasan nasabah mencakup perbedaan antara harapan nasabah dan kinerja atau hasil yang dirasakan. Pengertian ini didasarkan pada disconfirmation paradigma dari Oliver dalam Engel, et al; Pawitra, yang dikutip Tjiptono (2009). Dari beberapa definisi yang dikemukakan diatas dapat disimpulkan bahwa kepuasan nasabah merupakan suatu perasaan ataupun penilaian emosional dari nasabah atas penggunaan suatu produk barang atau jasa dimana harapan dan kebutuhan mereka terpenuhi.

Wilkie yang dikutip Tjiptono (2009). mengungkapkan bahwa indikator yang harus diperhatikan dalam mengukur kepuasan nasabah antara lain sebagai berikut: 1). Harapan (expectations); Harapan nasabah terhadap suatu barang atau jasa telah dibentuk sebelum nasabah membeli barang atau jasa tersebut. Pada saat proses pembelian dilakukan, nasabah berharap bahwa barang atau jasa yang mereka terima sesuai dengan harapan, keinginan, dan keyakinan mereka. Faktor - faktor yang mempengaruhi persepsi dan harapan nasabah adalah sebagai berikut : a). Kebutuhan dan keinginan yang berkaitan dengan hal-hal yang dirasakan nasabah ketika sedang mencoba melakukan transaksi dengan produsen produk (perusahaan). b). Pengalaman masa lalu ketika mengkonsumsi produk dari perusahaan maupun pesaing-pesaingnya. c). Pengalaman dari teman-teman. d). Komunikasi melalui iklan dan pemasaran. 2). Kinerja (performance); Performance merupakan pengalaman nasabah terhadap kinerja aktual barang atau jasa ketika digunakan tanpa dipengaruhi oleh 
harapan mereka. Selama mengkonsumsi suatu produk atau jasa, nasabah menyadari kegunaan produk aktual dan menerima kinerja produk tersebut sebagai dimensi yang penting bagi nasabah. 3). Perbandingan (comparison); Setelah mengkonsumsi barang atau jasa maka nasabah akan membandingkan harapan terhadap kinerja barang atau jasa sebelum membeli dengan kinerja aktual barang atau jasa tersebut. 4). Confirmation atau disconfirmation; Harapan pelanggan dipengaruhi oleh pengalaman nasabah terhadap penggunaan merek dari barang atau jasa yang berbeda atau dari pengalaman orang lain. Melalui penggunaan merek lain dan komunikasi dari perusahaan serta orang lain, nasabah membandingkan harapan kinerja barang atau jasa yang dibeli dengan kinerja aktual barang atau jasa tersebut. Confirmation terjadi ketika harapan sesuai dengan kinerja aktual produk. Disconfirmation terjadi ketika harapan lebih tinggi atau lebih rendah dari kinerja aktual produk. Nasabah akan merasa puas ketika terjadi confirmation dan disconfirmation yaitu ketika harapan melebihi kinerja aktual barang atau jasa. 5). Ketidaksesuaian (discrepancy); Discrepancy mengindikasikan bagaimana perbedaan antara level kinerja dengan harapan. Negatif disconfimations yaitu ketika kinerja aktual berada dibawah level harapan, kesenjangan yang lebih luas lagi akan mengakibatkan tingginya level ketidakpuasan. Sebaliknya positive disconfimations yaitu ketika kinerja aktual berada diatas level harapan. Ketika nasabah puas, maka nasabah akan menggunakan barang atau jasa yang sama, dan ketika nasabah merasa tidak puas maka nasabah akan menuntut perbaikan atau komplain terhadap perusahaan.

\section{Loyalitas Nasabah}

Secara harfiah loyal berarti setia, atau loyalitas dapat diartikan sebagai suatu kesetiaan. Kesetiaan ini diambil tanpa adanya paksaan, tetapi timbul dari kesadaran sendiri pada masa lalu. Usaha yang dilakukan untuk menciptakan kepuasan nasabah lebih cenderung mempengaruhi sikap nasabah. Sedangkan konsep loyalitas nasabah lebih menerangkan kepada perilaku pembelinya. Komitmen yang menyertai pembelian berulang tersebut adalah keadaan dimana konsumen tidak mau berpindah walaupun produk maupun jasa tersebut sedang langka dipasaran dan nasabah dengan sukarela merekomendasikan produk maupun jasa tersebut kepada rekan, keluarga atau konsumen yang lain. Menurut Rangkuti, (2002), "Loyalitas nasabah adalah kesetiaan nasabah terhadap perusahaan, merek maupun produk. Sutisna (2003) mendefinisikan loyalitas adalah sikap menyenangi terhadap suatu merek yang dipresentasikan dalam pembelian yang konsisten terhadap merek itu sepanjang waktu.

Durianto (2001) mengemukakan bahwa nasabah yang loyal pada umumnya akan melakukan pembelian merek tersebut walaupun dihadapkan pada banyak alternatif merek produk pesaing yang menawarkan karakteristik produk yang lebih unggul dipandang dari berbagai sudutnya. Dipandang dari berbagai sudut atributnya. Bila banyak nasabah dari suatu merek masuk dalam kategori ini, berarti mereka tersebut memiliki ekuitas merek yang kuat. Ekuitas merek adalah seperangkat harta dan hutang merek yang terkait dengan suatu merek, nama, simbol, yang mampu menambah atau mengurangi nilai yang diberikan oleh sebuah produk atau jasa baik pada perusahaan maupun pada nasabah.

Loyalitas nasabah merupakan ukuran yang dapat diandalkan untuk memprediksi pertumbuhan penjualan dan loyalitas pelanggan juga dapat didefinisikan berdasarkan perilaku pembelian yang konsisten (Griffin, 2005). Berikut ini ada lima karakteristik loyalitas konsumen yang perlu diperhatikan yaitu: 1). Melakukan pembelian ulang secara teratur. Konsumen melakukan pembelian secara terus-menerus pada suatu produk tertentu. 
2). Membeli antar lini produk dan jasa. Konsumen tidak hanya membeli jasa dan produk utama tetapi konsumen juga membeli lini produk dan jasa dari perusahaan yang sama. 3). Mereferensikan kepada orang lain. Dimana konsumen melakukan komunikasi dari mulut ke mulut (word of mouth) berkenan dengan produk tersebut. 4). Menunjukkan kekebalan terhadap tarikan dari pesaing. Konsumen menolak untuk menggunakan produk atau jasa alternatif yang ditawarkan oleh pesaing. Pelanggan yang loyal merupakan aset bagi perusahaan, hal ini dapat dilihat berdasarkan karateristik yang dimilikinya. Oleh karena itu, loyalitas konsumen merupakan suatu yang bisa diandalkan untuk memprediksi pertumbuhan dimasa yang akan datang bagi suatu perusahaan.

Hidayat (2009) mengemukakan bahwa loyalitas konsumen merupakan komitmen seorang konsumen terhadap suatu pasar berdasarkan sikap positif dan tercermin dalam pembelian ulang secara konsisten. Indikator dari loyalitas konsumen tersebut adalah: 1). Trust merupakan tanggapan kepercayaan konsumen terhadap pasar. 2). Emotion commitment merupakan komitmen psikologi konsumen terhadap pasar. 3). Switching cost merupakan tanggapan konsumen tentang beban yang diterima ketika terjadi perubahan. 4). Word of mouth merupakan perilaku publisitas yang dilakukan konsumen terhadap pasar. 5). Cooperation merupakan perilaku konsumen yang menunjukan sikap yang bekerja sama dengan pasar.

\section{Kerangka Konseptual}

Kerangka konseptual dalam penelitian ini menunjukkan bahwa kualitas layanan, citra merek, secara langsung dan tidak langsung memberikan pengaruh terhadap loyalitas nasabah dengan kepuasan nasabah sebagai variabel intervening. Adapun kerangka konseptual dalam penelitian ini dapat dilihat pada gambar-1.

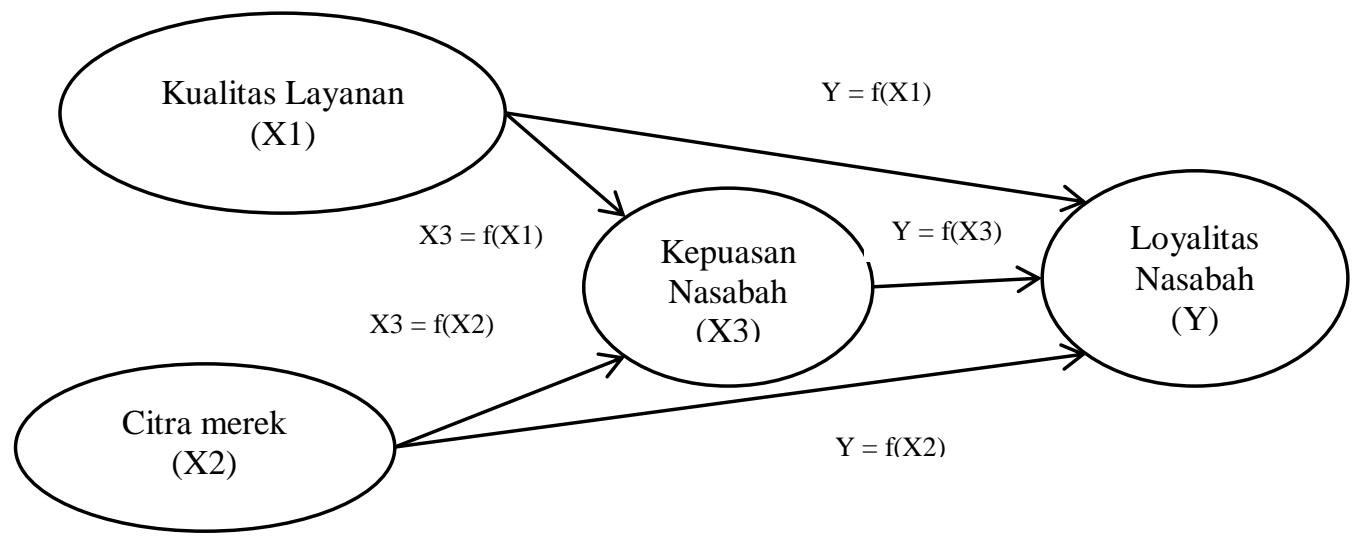

Gambar-1: Kerangka Konseptual

\section{Hipotesis}

Hipotesis dalam penelitian ini adalah sebagai berikut:

1. Diduga ada pengaruh secara langsung kualitas layanan terhadap kepuasan nasabah.

2. Diduga ada pengaruh secara langsung citra merek terhadap kepuasan nasabah.

3. Diduga ada pengaruh secara langsung kualitas layanan terhadap loyalitas nasabah.

4. Diduga ada pengaruh secara langsung citra merek terhadap loyalitas nasabah.

5. Diduga ada pengaruh secara langsung kepuasan nasabah terhadap loyalitas nasabah.

6. Diduga ada pengaruh kualitas layanan terhadap loyalitas nasabah melalui kepuasan 
nasabah.

7. Diduga ada pengaruh citra merek terhadap loyalitas nasabah melalui kepuasan nasabah.

\section{METODE PENELITIAN}

Penelitian ini menggunakan pendekatan explanatory analysis dan deskriptiive analysis, yang bertujuan untuk mengetahui pengaruh antara variabel bebas dan terikat. Populasi dalam penelitian ini adalah nasabah Perum Pegadaian Cabang Bekasi Timur yang datang minggu pertama bulan Desember 2017 sebanyak 45 orang. Teknik pengambilan sampel dalam penelitian ini menggunakan teknik sampling jenuh (sensus), yaitu teknik pemilihan sampel bila semua anggota populasi digunakan sebagai sampel. Hal ini dilakukan karena jumlah populasi relatif sedikit. Merujuk atas pernyataan tersebut, jumlah sampel yang digunakan adalah 45 orang.

Sebelum melakukan analisis data dan interpretasi, perlu diuji terlebih dahulu validitas dan reliabilitas data. Teknik analisis data yang digunakan adalah analisis jalur (path analisys) dengan menggunakan mediasi variabel kepuasan nasabah, dimana variabel kualitas layanan dan citra merek berdampak langsung terhadap loyalitas nasabah maupun variabel kualitas layanan dan citra merek berdampak tidak langsung atau mediasi variabel kepuasan nasabah terhadap loyalitas nasabah.

\section{HASIL PENELITIAN DAN PEMBAHASAN}

\section{Hasil Penelitian}

\section{Hasil uji validitas data dan uji reliabilitas}

Uji validitas digunakan menguji masing-masing variabel penelitian, dimana keseluruhan variabel penelitian memuat 40 pernyataan yang dijawab oleh 45 orang responden. Adapun kriteria yang digunakan dalam menentukan valid tidaknya pernyataan yang digunakan dalam penelitian ini adalah sebagai berikut: tingkat kepercayaan $=95$ persen (probabilitas atau $\alpha=5 \%$ ), derajat kebebasan $(\mathrm{dk})=\mathrm{n}-2=45-2=43$, didapat r-tabel $=0.294$. Jika r-hitung lebih besar dari r-tabel dan nilai $\mathrm{r}$ positif, maka butir pernyataan dikatakan valid (Ghozali, 2005). Dari 40 butir pertanyaan variabel yang digunakan (variabel kualitas layanan, citra merek, kepuasan nasabah, dan loyalitas nasabah) hasilnya adalah valid.

Uji reliabilitas untuk mengetahui sejauh mana hasil pengukurannya dapat diandalkan dan konsisten. Pada tabel 2, hasil pengujian berikut diketahui bahwa semua variabel mempunyai alpha di atas 0.60 yang berarti bahwa semua variabel dalam penelitian ini dapat diandalkan. Berdasarkan angka-angka reliabilitas cronbach alpha tersebut tampak bahwa semua pernyataan yang ada membentuk ukuran yang reliabel yaitu kualitas layanan, citra merek, kepuasan nasabah dan loyalitas nasabah membentuk ukuran yang reliabel dari masing-masing dimensi. 
Tabel 2: Hasil Uji Reliabilitas

\begin{tabular}{lccc}
\hline \multicolumn{1}{c}{ Variabel } & $\begin{array}{c}\text { Cronbach } \\
\text { Alpha }\end{array}$ & $\begin{array}{c}\text { Nilai kritis } \\
(\boldsymbol{\alpha})=\mathbf{5 \%}\end{array}$ & Keterangan \\
\hline Kualitas Layanan & 0.980 & 0.600 & Reliabel \\
Kualitas Produk & 0.978 & 0.600 & Reliabel \\
Kepuasan Nasabah & 0.974 & 0.600 & Reliabel \\
Loyalitas Nasabah & 0.985 & 0.600 & Reliabel \\
\hline
\end{tabular}

Sumber: Data diolah tahun 2017

\section{Analisis jalur}

Struktur 1:

Persamaan Struktur 1: $\mathrm{Y}_{1}=\mathrm{PY}_{1} \mathrm{X}_{1}+\mathrm{PY}_{1} \mathrm{X}_{2}+\epsilon_{1}$ $Y_{1}=0,204 X_{1}+0,186 X_{2}+0.032$

Tabel 3: Pengaruh Kualitas Layanan dan Citra Merek Terhadap Kepuasan Nasabah

\begin{tabular}{lccccc}
\hline \multirow{2}{*}{ Variabel } & \multicolumn{5}{c}{ Parameter } \\
\cline { 2 - 6 } & $\begin{array}{c}\text { Koefisien } \\
\text { Regresi }\end{array}$ & t-hitung & t-tabel & Sig & A \\
\hline Kualitas layanan & 0,204 & 3,102 & 2,017 & 0,000 & $5 \%$ \\
Citra merek & 0,186 & 6,393 & 0,000 & $5 \%$ \\
\hline
\end{tabular}

Sumber: Olah data, 2018

Berdasarkan tabel 3, koefisien kualitas layanan dan citra merek bertanda positif dan signifikan. Koefisien kualitas layanan dan citra merek bertanda positif, artinya jika kualitas layanan dan citra merek meningkat, maka akan meningkatkan kepuasan nasabah Perum Pegadaian Cabang Bekasi Timur. Hipotesis yang menyatakan bahwa terdapat pengaruh kualitas layanan dan citra merek terhadap kepuasan nasabah Perum Pegadaian Cabang Bekasi Timur terbukti.

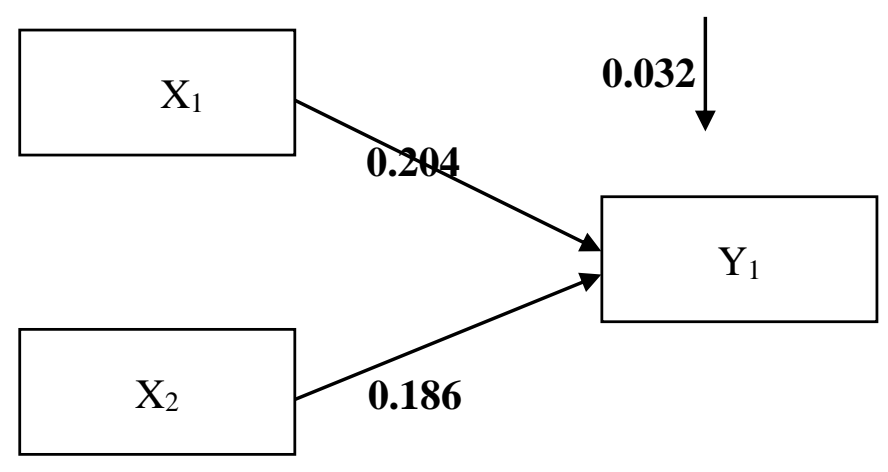

Gambar Persamaan Struktur 1 
Struktur 2:

Persamaan Struktur 2: $\mathrm{Y}_{2}=\mathrm{PY}_{2} \mathrm{X}_{1}+\mathrm{PY}_{2} \mathrm{Y}_{1}+\mathrm{PY}_{2} \mathrm{X}_{2}+\epsilon_{2}$ $\mathrm{Y}_{2}=0,168 \mathrm{X}_{1}+0,160 \mathrm{Y}_{1}+0,584 \mathrm{X}_{2}+0.011$

Tabel 4: Pengaruh Kualitas Layanan, Citra Merek dan Kepuasan Nasabah Terhadap Loyalitas Nasabah

\begin{tabular}{lccccc}
\hline \multirow{2}{*}{ Variabel } & \multicolumn{5}{c}{ Parameter } \\
\cline { 2 - 6 } & $\begin{array}{c}\text { Koefisien } \\
\text { Regresi }\end{array}$ & t-hitung & t-tabel & Sig & $\boldsymbol{\alpha}$ \\
\hline Kualitas layanan & 0,168 & 3,102 & & 0,000 & \\
Citra merek & 0,160 & 6,393 & 2,017 & 0,000 & $5 \%$ \\
Kepuasan nasabah & 0,584 & 1,710 & & 0,000 & \\
\hline
\end{tabular}

a. Dependent Variable: Loyalitas_Nasabah

Berdasarkan tabel 4, koefisien kualitas layanan, citra merek, dan kepuasan nasabah bertanda positif dan signifikan. Koefisien kualitas layanan, citra merek, dan kepuasan nasabah bertanda positif, artinya jika kualitas layanan, citra merek dan kualitas nasabah meningkat, maka akan meningkatkan kepuasan nasabah Perum Pegadaian Cabang Bekasi Timur. Hipotesis yang menyatakan bahwa terdapat pengaruh kualitas layanan, citra merek, dan kepuasan nasabah terhadap kepuasan nasabah Perum Pegadaian Cabang Bekasi Timur terbukti.

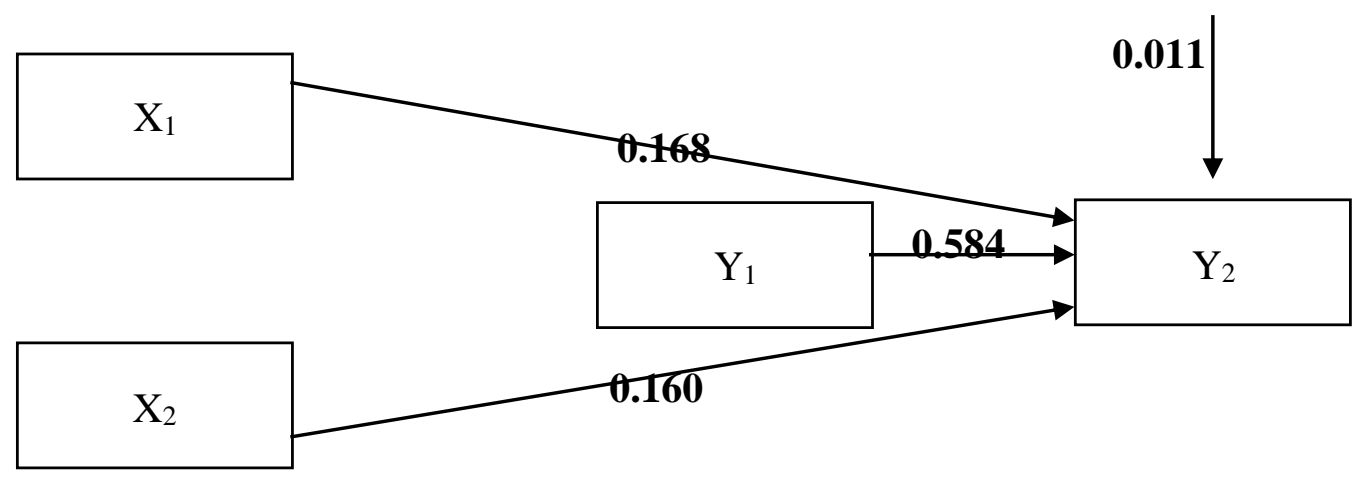

Gambar Persamaan Struktur 2

Perhitungan Pengaruh

1. Pengaruh langsung (direct effect atau DE) sebagai berikut:

a. Pengaruh variabel kualitas layanan terhadap kepuasan nasabah $\mathrm{X}_{1} \rightarrow \mathrm{Y}_{1}=0.204$

b. Pengaruh variabel citra merek terhadap kepuasan nasabah $\mathrm{X}_{2} \rightarrow \mathrm{Y}_{1}=0.186$

c. Pengaruh variabel kualitas layanan terhadap loyalitas nasabah $\mathrm{X}_{1} \rightarrow \mathrm{Y}_{2}=0.168$

d. Pengaruh variabel citra merek terhadap loyalitas nasabah $\mathrm{X}_{2} \rightarrow \mathrm{Y}_{2}=0.160$ 
e. Pengaruh variabel kepuasan nasabah terhadap loyalitas nasabah

$$
\mathrm{Y}_{1} \rightarrow \mathrm{Y}_{2}=0.584
$$

2. Pengaruh tidak langsung (Indirect Effect atau IE) sebagai berikut:

a. Pengaruh variabel kualitas layanan terhadap loyalitas nasabah melalui kepuasan nasabah

$$
\mathrm{X}_{1} \rightarrow \mathrm{Y}_{1} \rightarrow \mathrm{Y}_{2}=(0.204 \times 0.584)=0.119
$$

b. Pengaruh variabel citra merek terhadap loyalitas nasabah melalui kepuasan nasabah $\mathrm{X}_{2} \rightarrow \mathrm{Y}_{1} \rightarrow \mathrm{Y}_{2}=(0.186 \times 0.584)=0.109$

3. Pengaruh total (total effet)

a. Pengaruh variabel kualitas layanan terhadap loyalitas nasabah melalui kepuasan nasabah

$$
\mathrm{X}_{1} \rightarrow \mathrm{Y}_{1} \rightarrow \mathrm{Y}_{2}=(0.204+0.584)=0.788
$$

b. Pengaruh variabel citra merek terhadap loyalitas nasabah melalui kepuasan nasabah $\mathrm{X}_{2} \rightarrow \mathrm{Y}_{1} \rightarrow \mathrm{Y}_{2}=(0.186+0.584)=0.770$

c. Pengaruh variabel kualitas layanan terhadap loyalitas nasabah $\mathrm{X}_{1} \rightarrow \mathrm{Y}_{2}=0.168$

d. Pengaruh variabel citra merek terhadap loyalitas nasabah $\mathrm{X}_{2} \rightarrow \mathrm{Y}_{2}=0.160$

e. Pengaruh variabel kepuasan nasabah terhadap loyalitas nasabah $\mathrm{Y}_{1} \rightarrow \mathrm{Y}_{2}=0.584$

\section{Pembahasan}

Pengaruh kualitas layanan dan citra merek terhadap kepuasan nasabah; kualitas layanan memiliki pengaruh yang lebih besar dalam pembentukan kepuasan nasabah dibandingkan citra merek. Pernyataan ini memberikan arti bahwa perusahaan dalam membentuk kepuasan nasabah dapat memprioritaskan pada kualitas layanan kemudian diikuti oleh pembentukan citra merek. Penelitian ini sejalan dengan penelitian yang dilakukan oleh Susanto, (2012) dan Enggarwati, et al. (2017) yang menjelaskan bahwa citra merek, kualitas layanan berpengaruh terhadap loyalitas pelanggan yang dimediasi oleh kepuasan konsumen.

Pengaruh kualitas layanan dan citra merek terhadap loyalitas nasabah; kualitas layanan memiliki pengaruh yang lebih besar dalam pembentukan loyalitas nasabah dibandingkan citra merek. Pernyataan ini memberikan arti bahwa perusahaan dalam membentuk loyalitas nasabah dapat memprioritaskan pada kualitas layanan kemudian diikuti oleh pembentukan citra merek. Penelitian ini sejalan dengan penelitian yang dilakukan oleh Fajarianto, et al. 2013 dan Enggarwati, et al. (2017) yang menjelaskan bahwa kualitas layanan dan brand image berpengaruh terhadap loyalitas pelanggan melalui kepuasan pelanggan.

Dari pengaruh langsung dan tidak langsung didapat bahwa pengaruh langsung lebih kecil dari nilai pengaruh tidak langsung yang memberikan arti bahwa variabel kepuasan nasabah mampu memediasi kualitas layanan dan citra merek terhadap loyalitas nasabah. 


\section{KESIMPULAN DAN SARAN \\ Kesimpulan}

Berdasarkan hasil penelitian dan pembahasan, dapat disimpulkan bahwa secara parsial masing-masing kualitas layanan, citra merek dan kepuasan nasabah mendorong peningkatan loyalitas nasabah Perum Pegadaian Cabang Bekasi Timur. Kemudian hasil analisis kepuasan nasabah sebagai variabel intervening dapat dibuktikan dengan sempurna yaitu kepuasan nasabah memberikan dukungan tidak langsung kepada kualitas layanan terhadap loyalitas nasabah dan citra merek terhadap loyalitas nasabah. Pernyataan ini dapat dibuktikan oleh besarnya dukungan tidak langsung (kualitas layanan terhadap loyalitas nasabah dan citra merek terhadap loyalitas nasabah) melalui kepuasan nasabah yang diidentifikasi sebagai variabel intervening.

\section{Saran}

1. Layanan yang berkualitas dapat dijadikan komponen utama dalam pemberian layanan, sehingga dapat memberikan dukungan kepada nasabah yang kemudian menjadi bahan pertimbangan dalam keputusan nasabah untuk menggunakan jasa Perum Pegadaian Cabang Bekasi Timur. Selain itu, memberikan layanan yang berkualitas adalah salah satu upaya untuk menjaga nasabah agar terciptanya sikap loyalitas dari nasabah untuk tetap menggunakan jasa Perum Pegadaian Cabang Bekasi Timur.

2. Citra merek Perum Pegadaian Cabang Bekasi Timur umumnya suduh cukup baik, namun lebih baik lagi apabila memperhatikan mengenai kesan nasabah dengan memberikan desain dan layanan yang lebih modern agar lebih meningkatkan kesan citra merek yang lebih kuat.

3. Dalam upaya meningkatkan kepuasan nasabah, manajemen perusahaan dapat terus meningkatkan kualitas layanan yang diberikan, sehingga selain kepuasan nasabah dapat terus dijaga juga dapat membantu dalam memperluas jaringan bisnisnya hingga ke seluruh daerah di Indonesia baik di perkotaan maupun jangkauannya pada daerah pedesaan.

4. Hasil penelitian ini masih jauh dari kesempurnaan. Untuk itu, perlu dilakukan penelitian lanjutan yang lebih memperhatikan penetapan indicator, dimana dalam penetapan indikator dapat disesuaikan dengan tempat maupun objek penelitian yang ditetapkan. Kemudian disisi lain kelemahan penelitian ini dapat dilihat dari penggunaan jumlah sampel yang digunakan. Dimana keterbatasan jumlah responden dalam penelitian ini dapat berdampak pada akurasi dan validasi data-data yang dihimpun dan dianalisis.

\section{DAFTAR PUSTAKA}

Durianto, Darmadi., Sugiarto, dan Tony Sitinjak., 2001, Strategi Menaklukkan Pasar Melalui Riset Ekuitas dan Perilaku Merek. Jakarta: Gramedia Pustaka Utama.

Enggarwati, Pramita,. Sumiati dan Sunaryo. 2017. Pengaruh Citra Merek, Kualitas Layanan terhadap Loyalitas Pelanggan yang Dimediasi oleh Kepuasan Konsumen (Studi pada Butik Zoya di Kota Malang). Jurnal Bisnis dan Manajemen Vol. 4 No. 1, Januari 2017. Hal. 45-54. 
Fajarianto, Bayu,. Lubis, Nawazirul dan Suryadi. 2013. Pengaruh Kualitas Layanan dan Brand Image terhadap Loyalitas Pelanggan Melalui Kepuasan Pelanggan (Studi Kasus pada CV. AHASS Sahabat Sejati Motor Tembalang Semarang). Diponegoro Journal of Social and Politic. Tahun 2013, Hal. 1-12.

Ghozali, Imam. 2002. Aplikasi Analisis Multivariate dengan Program SPSS. (4 ${ }^{\text {th }}$ ed). Semarang: Badan Penerbit Undip.

Griffin, Jill, 2005. Customer Loyalty: Menumbuhkan dan Mempertahankan Kesetiaan Pelanggan. Jakarta: Erlangga.

Hidayat, Aziz. 2009. Metode Penelitian Keperawatan dan Tekhnik Analisis Data. Jakarta: Salemba Medika.

Keller, L.L. 1993. Conceptualising, Measuring and Managing Customer Based Brand Equity. Journal of Marketing. (57) 1:1-22.

Kotler dan Keller. 2009. Manajemen Pemasaran. Jilid I. Edisi ke 13. Jakarta: Erlangga.

Kotler, Philip dan Gary Amstrong. 2009. Manajemen Pemasaran. Jakarta: PT INDEKS Kelompok Gramedia.

Rangkuti, Freddy 2002. Measuring Customer Satisfaction Teknik Mengukur dan Strategi Meningkatkan Kepuasan Pelanggan dan Analisis Kasus PLN-JP. Jakarta: PT. Gramedia Pustaka Utama.

Roslina. 2010. Citra Merek: Dimensi, Proses Pemngembangan serta Pengukurannya. Jurnal Bisnis dan Manajemen, Volume 6 No 3, Mei 2010: 333-346.

Sugiyono. 2009. Metode Penelitian Kuantitatif, Kualitatif dan R\&D. Bandung: Alfabeta.

Susanto, Perengki. 2012. Pengaruh Kualitas Layanan Akademik dan Citra Merek Lembaga Terhadap Kepuasan Mahasiswa Universitas Negeri Padang. Jurnal Tingkap Vol. VIII No. I Th. 2012. Hal 65-77

Sutisna. 2003. Perilaku Konsumen dan Komunikasi Pemasaran. Cetakan Ketiga. Bandung: PT Remaja Posdakarya.

Tjiptono. 2009. Strategi Pemasaran. Edisi Kedua. Cetakan Ketujuh. Yogyakarta: Andi Offset.

Tjiptono, Fandy 2011. Strategi Pemasaran. Edisi 3. Yogyakarta: Andi Offset.

Tjiptono, Fandy. 2011. Pemasaran Jasa. Malang: Bayumedia.

Zeithaml dan Bitner dalam Jurnal Academy of Marketing Science http://www.amsreview.com. 